\title{
Health status of winter triticale under conversion from the conventional production to organic systems
}

\section{Zdrowotność pszenżyta ozimego w warunkach przestawiania produkcji konwencjonalnej na ekologiczną}

\author{
Tomasz P. Kurowski ${ }^{1}$, Marta Damszel ${ }^{1}$, Urszula Wysocka ${ }^{1}$, Tadeusz Sadowski ${ }^{2}$, Bogumił Rychcik ${ }^{2}$
}

\begin{abstract}
Summary
Winter triticale cultivar Witon was grown in 2004-2006 on the experimental plots in Bałcyny (NE Poland). The first two years of conducting the experiment referred to a period of converting the conventional production system to organic. Organic crop production started in 2006. The results of the experiment, showed that the average root rot infection index was higher in the organic farming system (22.4\%) than in the conventional system (17.4\%), in contrast to the data on the severity of stem base diseases, eyespot and fusarium foot rot $(17.9,31.8 \%$ and $30.7,35.8 \%$ in the organic and conventional systems, respectively). Fungicides used in the conventional farming system effectively reduced the development of cereal leaf pathogens. The symptoms of infection caused by Puccinia recondita were recorded only in the organic farming system (35.0\%). The severity of tan spot of cereals reached $94.0 \%$ in the organic system, and only $6.0 \%$ in the conventional system.
\end{abstract}

Key words: winter triticale, sanitary state, conventional system, organic system, conversion

\section{Streszczenie}

Pszenżyto ozime odmiany Witon uprawiano w latach 2004-2006 na poletkach doświadczalnych w Bałcynach. Dwa lata badań $(2004,2005)$ stanowiły okres przestawiania produkcji na uprawę metodami ekologicznymi, a kolejny, zgodnie z obowiązującym rozporządzeniem był już uprawą w systemie ekologicznym. Średni indeks porażenia korzeni w okresie badań był wyższy w ekologicznym systemie gospodarowania (22,4\%) niż w konwencjonalnym (17,4\%). Odwrotnie przedstawiało się nasilenie chorób podstawy źdźbła - łamliwości źdźbła zbóż i fuzaryjnej zgorzeli podstawy źdźbła (odpowiednio 17,9 i 31,8\% oraz 30,7 i 35,8\% w systemie ekologicznym i konwencjonalnym). Użyte fungicydy w systemie konwencjonalnym skutecznie hamowały rozwój patogenów aparatu asymilacyjnego. Objawy powodowane przez Puccinia recondita odnotowano jedynie w systemie ekologicznym 35,0\%. Nasilenie objawów brunatnej plamistości liści w systemie ekologicznym wynosiło 94,0\%, a w konwencjonalnym jedynie 6,0\%.

Słowa kluczowe: pszenżyto ozime, system konwencjonalny, system ekologiczny, konwersja, zdrowotność

\footnotetext{
Uniwersytet Warmińsko-Mazurski w Olsztyni

${ }^{1}$ Katedra Fitopatologii i Entomologii

Prawocheńskiego 17, 10-721 Olsztyn

kurowski@uwm.edu.pl

${ }^{2}$ Katedra Systemów Rolniczych

Plac Łódzki 3, 10-718 Olsztyn
} 


\section{Wstęp / Introduction}

Optymalne plonowanie i dobrą zdrowotność pszenżyta uzyskuje się stosując konwencjonalne metody gospodarowania, zaś w przypadku upraw ekologicznych może ono podlegać silnej presji patogenów. Zdrowotność pszenżyta w dużej mierze zależy od panujących warunków atmosferycznych (Szwejkowski i Kurowski 2003). Na stan zdrowotny pszenżyta mają wpływ wzajemne oddziaływania kompleksu czynników abiotycznych i biotycznych, w tym pochodzenia antropogenicznego. Wyniki badań ostatnich lat wskazują na wzrost nasilenia występowania chorób aparatu asymilacyjnego i podstawy źdźbła tego gatunku (Wakuliński i wsp. 2005; Weber i Hryńczuk 2005). Z kolei system dopłat jest czynnikiem powodującym przechodzenie większej liczby gospodarstw na produkcję w systemie ekologicznym, w którym nie stosuje się chemicznych metod ograniczania patogenów roślin. Dlatego ważne jest monitorowanie zdrowotności pszenżyta ozimego uprawianego metodą konwencjonalną i ekologiczną, z uwzględnieniem etapu konwersji, którego zadaniem jest indukcja równowagi interakcji patognantagonista i poprawa biologicznych właściwości gleby (Tyburski i Żakowska-Biemans 2007).

\section{Materiały i metody / Materials and methods}

Pszenżyto odmiany Witon uprawiano na poletkach doświadczalnych w Bałcynach (53,6 N, 19,85 E) na glebie średnio zwięzłej, kompleksu pszennego dobrego i żytniego bardzo dobrego, według zasad rolnictwa konwencjonalnego i ekologicznego. Dwa lata badań (2004, 2005) stanowiły okres przestawiania na produkcję metodami ekologicznymi, a kolejny, zgodnie z obowiązującym rozporządzeniem (Rozporządzenie 1991), stanowił już uprawę w systemie ekologicznym. W systemie ekologicznym pszenżyto ozime uprawiano w płodozmianie 6-polowym okopowym. Uwzględniono siłę nawozową przedplonu (przedprzedplon - ziemniak na oborniku, przedplon - orkisz ozimy) oraz bronowanie jako mechaniczny zabieg pielęgnacyjny. W systemie konwencjonalnym pszenżyto uprawiano w płodozmianie 6-polowym, zbożowym, w którym stosowano nawożenie mineralne: $\mathrm{N}-80 \mathrm{~kg} / \mathrm{ha}, \mathrm{P}_{2} \mathrm{O}_{5}-60 \mathrm{~kg} / \mathrm{ha} \mathrm{i} \mathrm{K}_{2} \mathrm{O}-100 \mathrm{~kg} / \mathrm{ha}$ oraz regulowano zachwaszczenie (Mocarz 75 WG, Puma Universal 069 EW + Starane 250 EC). W ochronie

Tabela 1. Środki ochrony roślin stosowane w uprawie pszenżyta ozimego

Table 1. Pesticides used in the cultivation of winter tirticale

\begin{tabular}{c|l|l}
\hline $\begin{array}{c}\text { Lp. } \\
\text { No. }\end{array}$ & \multicolumn{1}{|c|}{$\begin{array}{c}\text { Środek ochrony roślin } \\
\text { Pesticide }\end{array}$} & \multicolumn{1}{|c}{$\begin{array}{c}\text { Substancja czynna } \\
\text { Active substance }\end{array}$} \\
\hline 1. & Mocarz 75 WG & dicamba, tritosulfuron \\
\hline 2. & Puma Universal 069 EW & fenoxaprop-P-ethyl \\
\hline 3. & Starane 250 EC & fluroxypyr \\
\hline 4. & Alert 375 SC & flusilazol + carbendazym \\
\hline 5. & Amistar 250 SC & azoksystrobin \\
\hline
\end{tabular}

chemicznej przed patogenami użyto fungicydów: Alert 375 SC (BBCH 30-31) i Amistar 250 SC (BBCH 51-53). Zabiegi prowadzono zgodnie z zaleceniami (tab. 1).

Zdrowotność korzeni (BBCH 55) oceniano metoda Łacicowej (1970), liści i kłosów (BBCH 75) metodą Hinfnera i Pappa (1964), a zdrowotność podstawy źdźbła (BBCH 85) według metody Mackiewicza i Drath (1972). Uzyskane wyniki przedstawiono $\mathrm{w}$ postaci indeksu porażenia, obliczonego według wzoru Mc Kinneya (Łacicowa 1970). Istotność różnic oszacowano korzystając z programu Statistica 8, przy użyciu testu Duncana na poziomie istotności 0,05 .

\section{Wyniki i dyskusja / Results and discussion}

Średni indeks porażenia korzeni w okresie badań w ekologicznym systemie gospodarowania wyniósł 22,4\%, a w konwencjonalnym 17,4\% (rys. 1). Badania Lemańczyka (2009) również wykazały zróżnicowane nasilenie chorób korzeni pszenicy ozimej w zależności od systemu gospodarowania, przy czym najwyższe porażenie odnotowano, gdy zboże uprawiano w uproszczonym aż do monokultury systemie konwencjonalnym. Znacznie niższy stopień porażenia stwierdzono w systemie integrowanym, a następnie w ekologicznym. Najzdrowsze korzenie, podobnie jak w badaniach własnych, odnotowano w zmianowaniu w systemie konwencjonalnym. Parylak i wsp. (2010) wykazali korzystny wpływ zaprawiania materiału siewnego na ograniczenie chorób zgorzelowych pszenżyta ozimego, co dowodzi skuteczności zabiegów chemicznych w konwencjonalnej uprawie zbóż.

We wszystkich latach badań na liściach pszenżyta obserwowano septoriozy liści (Septoria spp.), a w jednym roku odnotowano rdzę brunatną (Puccinia recondita) oraz brunatną plamistość liści (Drechslera tritici-repentis). W konwencjonalnym systemie gospodarowania, w całym okresie badań nasilenie septorioz liści było niewielkie i stosunkowo wyrównane (rys. 1). W związku ze skutecznością zastosowanych fungicydów Ip wahał się w granicach od 1,3 do 4,3\%. Porażenie przez Septoria spp. roślin uprawianych według zasad rolnictwa ekologicznego w pierwszych dwóch latach badań było również niewielkie, Ip nie przekraczał 8,5\%, natomiast w 2006 roku w systemie tym odnotowano $25,0 \%$ indeks porażenia. Średnio w okresie badań zdecydowanie silniej porażone były rośliny uprawiane $\mathrm{w}$ systemie ekologicznym niż konwencjonalnym (odpowiednio 13,2 i 2,9\%). Na liściach pszenżyta uprawianego w ekologicznym systemie gospodarowania w 2005 roku odnotowano objawy chorobowe powodowane przez $P$. recondita i objęły one około $35 \%$ powierzchni liści. Zastosowane w systemie konwencjonalnym fungicydy skutecznie chroniły aparat asymilacyjny pszenżyta przed tym patogenem. Rośliny zainfekowane przez $D$. tritici-repentis notowano w 2006 roku, w obydwu systemach gospodarowania (tab. 2).

W systemie ekologicznym porażenie roślin przez tego patogena było zdecydowanie wyższe niż w systemie konwencjonalnym (odpowiednio 94,0 i 6,0\%). Wiadomo, że ciepła i wilgotna wiosna sprzyja wysokiemu nasileniu objawów chorobowych aparatu asymilacyjnego zbóż 
Tabela 2. Indeks porażenia [\%] liści i podstawy źdźbła pszenżyta

Table 2. The index infection of leaf and stem base infection index of winter triticale

\begin{tabular}{|c|c|c|c|c|c|c|}
\hline \multirow{2}{*}{$\begin{array}{l}\text { Choroba patogen } \\
\text { Disease pathogen }\end{array}$} & \multirow{2}{*}{$\begin{array}{l}\text { Część rośliny } \\
\text { Part of plants }\end{array}$} & \multirow{2}{*}{$\begin{array}{l}\text { Rok } \\
\text { Year }\end{array}$} & \multirow{2}{*}{$\begin{array}{c}\text { faza } \\
\text { rozwojowa } \\
{[\mathrm{BBCH}]}\end{array}$} & \multicolumn{2}{|c|}{$\begin{array}{l}\text { System gospodarowania } \\
\text { Farming system }\end{array}$} & \multirow{2}{*}{$\begin{array}{c}\text { NIR } \\
(0,05) \\
\text { LSD } \\
(0.05)\end{array}$} \\
\hline & & & & $\begin{array}{l}\text { ekologiczny } \\
\text { organic }\end{array}$ & $\begin{array}{l}\text { konwencjonalny } \\
\text { conventional }\end{array}$ & \\
\hline $\begin{array}{l}\text { Rdza brunatna } \\
\text { Puccinia recondita }\end{array}$ & $\begin{array}{l}\text { liść } \\
\text { leaf }\end{array}$ & 2005 & 75 & 35,0 & 0,0 & 12,41 \\
\hline $\begin{array}{l}\text { Brunatna plamistość liści } \\
\text { Drechslera tritici-repentis }\end{array}$ & $\begin{array}{l}\text { liść } \\
\text { leaf }\end{array}$ & 2006 & 75 & 94,0 & 6,0 & $\begin{array}{l}9,68 \\
6,59\end{array}$ \\
\hline $\begin{array}{l}\text { Ostra plamistość oczkowa } \\
\text { Rhizoctonia spp. }\end{array}$ & $\begin{array}{l}\text { podstawa źdźbła } \\
\text { stem base }\end{array}$ & $\begin{array}{l}2004 \\
2005\end{array}$ & 85 & $\begin{array}{l}0,0 \\
4,0\end{array}$ & $\begin{array}{l}1,3 \\
0,0\end{array}$ & $\begin{array}{l}\text { r.n. } \\
\text { r.n. }\end{array}$ \\
\hline $\begin{array}{l}\text { Zgorzel podstawy źdźbła } \\
\text { Gaeumannomyces graminis }\end{array}$ & $\begin{array}{l}\text { podstawa źdźbła } \\
\text { stem base }\end{array}$ & 2004 & 85 & 6,0 & 8,7 & r.n. \\
\hline
\end{tabular}

r.n. - różnice nieistotne - not significant differences; NIR - LSD - najmniejsza istotna różnica - least significant difference

(Kurowski i Adamiak 2001), co tłumaczy silny pojaw patogenów w 2006 roku, charakteryzującym się wysoką temperaturą i obfitymi opadami.

Spośród chorób podstawy źdźbła, corocznie i w największym nasileniu występowała fuzaryjna zgorzel podstawy źdźbła (Fusarium spp.), a w nieco mniejszym łamliwość źdźbła zbóż i traw (Tapesia spp.) (rys. 1). W dwóch latach obserwowano także pojedyncze rośliny z typowymi objawami ostrej plamistości oczkowej (Rhizoctonia cerealis), a w jednym zgorzeli podstawy źdźbła (Gaeumannomyces graminis) (tab. 2).

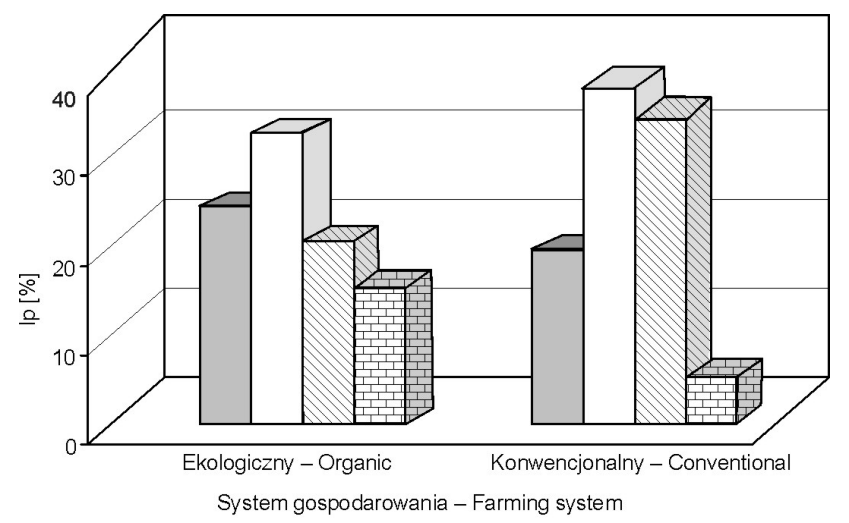

Zgorzel korzeni - Root roots

$\square$ Fuzaryjna zgorzel podstawy źdźbła - Fusarium foot rot

Łamliwość źdźbła zbóż i traw - Eyespot

曰 Septorioza liści - Leaf bloth

Rys. 1. Indeks porażenia dominujących chorób pszenżyta ozimego w zależności od systemu uprawy w latach 2004-2006

Fig. 1. Index infection of winter triticale dominant diseases in realtion to farming system in 2004-2006

Fuzaryjna zgorzel podstawy źdźbła w pierwszym i trzecim roku badań $(2004,2006)$ opanowała podstawy źdźbła pszenżyta ozimego na zbliżonym poziomie w obydwu systemach gospodarowania. W 2005 roku, kiedy w konwencjonalnym systemie gospodarowania nie zastosowano chemicznej ochrony roślin, porażenie roślin przez grzyby rodzaju Fusarium było zdecydowanie wyższe niż w ekologicznym (odpowiednio 24,0 i 7,3\%). Średni indeks porażenia za cały okres badań wyniósł w ekologicznym systemie gospodarowania $30,7 \%$, a w konwencjonalnym $35,8 \%$.

Nasilenie łamliwości źdźbła zbóż było zróżnicowane w latach badań. Niezależnie od systemu gospodarowania najwyższy udział roślin porażonych przez grzyby rodzaju Tapesia wystapił w 2005 roku, a najniższy w 2006 roku. $\mathrm{Na}$ roślinach uprawianych według zasad rolnictwa konwencjonalnego w pierwszych dwóch latach badań notowano wyższe nasilenie choroby niż w systemie ekologicznym, jednak różnice stwierdzone w pierwszym roku okazały się statystycznie nieistotne. W 2006 roku udział porażonych roślin był wyższy w systemie ekologicznym. Indeks porażenia wyniósł ponad 9,0\%, podczas gdy w systemie konwencjonalnym nie przekraczał 2,0\%. Średnio w okresie badań zdecydowanie silniej były porażone rośliny uprawiane $\mathrm{w}$ systemie konwencjonalnym niż ekologicznym (odpowiednio 31,8 i 17,9\%). Ostra plamistość oczkowa wystąpiła w niewielkim nasileniu. W 2004 roku objawy choroby odnotowano tylko w konwencjonalnym systemie gospodarowania, gdzie indeks porażenia wyniósł $1,3 \%$, natomiast w 2005 roku występowanie $R$. cerealis obserwowano wyłącznie na roślinach uprawianych zgodnie z zasadami rolnictwa ekologicznego (Ip - 4,0\%). Występowanie zgorzeli podstawy źdźbła odnotowano jedynie w pierwszym roku badań na roślinach uprawianych w obu systemach gospodarowania. Średni Ip wynosił w systemie ekologicznym 6,0\%, a w konwencjonalnym $8,7 \%$. Zgodnie z wcześniejszymi doniesieniami (Majchrzak 1985; Kurowski 2002; Jaczewska-Kalicka 2006; Wojtala i Parylak 2009) zgorzel podstawy źdźbła i ostra plamistość oczkowa nie miały większego znaczenia gospodarczego. Symptomy tych chorób obserwowane w pierwszych latach badań wskazują na możliwość kumulowania w agrocenozach form przetrwalnikowych patogenów i konieczność monitorowania ich aktywności zarówno w okresie konwersji, jak i właściwej produkcji roślinnej metodami ekologicznymi. Ponadto, według 
niektórych autorów, zmiany składu mikroorganizmów w środowisku glebowym w systemie ekologicznym moga być niewystarczające $i$ nie na tyle korzystne, aby zabezpieczyć rośliny przed patogenami grzybowymi (Lenc i wsp. 2005), szczególnie w okresie przestawiania gospodarstwa na produkcję metodami ekologicznymi (Jończyk i Solarska 2004), kiedy dopiero następuje nadanie glebie wysokiej aktywności biologicznej (Tyburski i ŻakowskaBiemans 2007).

\section{Wnioski / Conclusions}

1. Okres konwersji stanowił etap wzbudzania naturalnej odporności roślin uprawnych przez kształtowanie nowych zależności między mikroorganizmami zasiedlającymi agrocenozy.

2. Chemiczna ochrona roślin skutecznie obniżyła nasilenie chorób aparatu asymilacyjnego oraz korzeni pszenżyta ozimego, natomiast naturalne sprzężenia zwrotne w agroekosytemie uprawianym metodą ekologiczną pozytywnie wpływały na zdrowotność podstawy źdźbła.

3. Podczas przestawiania produkcji roślinnej $\mathrm{z}$ konwencjonalnej na ekologiczną wystąpiły wyraźne zmiany w nasileniu poszczególnych chorób.

4. Należy monitorować i przewidywać skutki selekcji mikroorganizmów glebowych, ponieważ może łączyć się z tym kompensacja rozwoju zarówno patogenów, jak i ich antagonistów.

\section{Literatura / References}

Hinfner K., Paap Z.S. 1964. Atlas Chorób i Szkodników Zbóż i Kukurydzy. PWRiL, Warszawa, 206 ss.

Jaczewska-Kalicka A. 2006. Zmienność nasilenia rozwoju chorób grzybowych pszenicy ozimej w latach 2001-2005. Prog. Plant Prot./Post. Ochr. Roślin 46 (1): 451-460.

Jończyk K., Solarska E. 2004. Zdrowotność pszenicy ozimej uprawianej w ekologicznym i konwencjonalnym systemie produkcji roślinnej. Prog. Plant Prot./Post. Ochr. Roślin 44 (2): 772-775.

Konieczny M. 2005. Grzyb Blumeria graminis (DC) Speer poważnym zagrożeniem dla pszenżyta. Prog. Plant Prot./Post. Ochr. Roślin 45 (2): 505-510.

Kurowski T., Adamiak E. 2001. Możliwość ograniczenia szkodliwego oddziaływania monokultury na zdrowotność i plonowanie pszenicy ozimej przez stosowanie fungicydów. Prog. Plant Prot./Post. Ochr. Roślin 41 (2): 755-757.

Kurowski T.P. 2002. Studia nad chorobami podsuszkowymi zbóż uprawianych w wieloletnich monokulturach. UWM, Olsztyn, Rozprawy i Monografie, 56 ss.

Lemańczyk G. 2009. Zdrowotność korzeni pszenicy ozimej odmiany Sukces i zasiedlające je grzyby w zależności od systemu uprawy. s. 70-73. W: „Nowe osiaggnięcia w biologicznej ochronie roślin przed chorobami”. Bydgoszcz-Ciechocinek, 28-29 maja 2009, $100 \mathrm{ss}$.

Lenc L., Pańka D., Sadowski Cz. 2005. Zbiorowiska grzybów środowiska glebowego ziemniaka (Solanum tuberosum L.) uprawianego w systemie ekologicznym i integrowanym. s. 788-793. W: „Obieg Pierwiastków w Przyrodzie”. Bioakumulacja-ToksycznośćPrzeciwdziałanie. Monografia. Tom 3 (B. Gworek, red.). Instytut Ochrony Środowiska, Warszawa, 828 ss.

Łacicowa B. 1970. Badanie szczepów Helminthosporium sorokinianum (=H. sativum) oraz odporności jęczmienia jarego na ten czynnik chorobotwórczy. Acta Mycol. 6 (2): 184-248.

Mackiewicz D., Drath I. 1972. Wpływ zmianowania na stopień porażenia pszenicy przez łamliwość źdźbeł oraz na jej plonowanie. Biul. Inst. Ochr. Roślin 54: 153-169.

Majchrzak B. 1985. Wpływ zespołu grzybów glebowych na patogeny powodujące zgorzele podstawy źdźbła i korzeni pszenicy ozimej. Rocz. Nauk Rol. 15 (1-2): 39-50.

Parylak D., Paluch M., Wojtala-Łozowska L. 2010. Ocena możliwości ograniczania porażenia pszenżyta ozimego uprawianego po sobie przez choroby podstawy źdźbła. Prog. Plant Prot./Post. Ochr. Roślin 50 (2): 695-699.

Rozporządzenie Rady nr 2092/91/EWG z dnia 24 czerwca 1991 r. w sprawie produkcji ekologicznej produktów rolnych oraz znakowania produktów rolnych i produktów spożywczych, 107 ss.

Szwejkowski Z., Kurowski T.P. 2003. Badania wpływu czynników pogodowych na stopień inwazyjności patogenów grzybowych w środowisku na przykładzie pszenicy ozimej. Przegl. Nauk. Inż. Kształt. Środ. (26): 83-90.

Tyburski J., Żakowska-Biemans S. 2007. Wprowadzenie do Rolnictwa Ekologicznego. Wyd. SGGW, Warszawa, 280 ss.

Wakuliński W., Zamorski Cz., Nowicki B., Schollenberger M., Mirzwa-Mróz E., Mikulski W., Konieczny M. 2005. Grzyb Blumeria graminis (DC) Speer poważnym zagrożeniem dla pszenżyta. Prog. Plant Prot./Post. Ochr. Roślin 45 (1): 505-510.

Weber R., Hryńczuk B. 2005. Choroby podstawy źdźbła owsa i pszenżyta ozimego w zależności od sposobu uprawy wieloletniego odłogu. Fragm. Agron. 2: 249-257.

Wojtala L., Parylak D. 2009. Skuteczność zapraw nasiennych, międzyplonu i poziomu nawożenia azotowego w ograniczaniu porażenia pszenicy ozimej przez patogeny podstawy źdźbła. Prog. Plant Prot./Post. Ochr. Roślin 49 (2): 769-772.

Praca wydrukowana w Vol. 52 (4) 2012.

$\mathrm{Z}$ powodów technicznych uzupełniona i wydrukowana ponownie. 